\title{
Prevalence and genotypes of hepatitis $C$ virus among injecting drug users from Salvador-BA, Brazil
}

\author{
Maria Betânia S Silva', Tarcísio M Andrade ${ }^{2}$, Luciano K Silva', Itatiana F Rodart', Gisele B Lopes ${ }^{1}$, \\ Theomira MA Carmo ${ }^{1}$, Maria Alice S Zarife ${ }^{3}$, Inês Dourado ${ }^{4}$, Mitermayer G Reis ${ }^{1 /+}$
}

1'Laboratório de Patologia e Biologia Molecular, Centro de Pesquisa Gonçalo Moniz-Fiocruz, R. Waldemar Falcão 121, 40295-001 Salvador, BA, Brasil ${ }^{2}$ Aliança de Redução de Danos Fátima Cavalcanti ${ }^{4}$ Instituto de Saúde Pública, Universidade Federal da Bahia, Salvador, BA, Brasil ${ }^{3}$ Laboratório Central da Bahia, Departamento de Saúde da Bahia, Salvador, BA, Brasil

Hepatitis $C$ virus (HCV) is the major infectious disease agent among injecting drug users (IDUs), with seroprevalence ranging from 50-90\%. In this paper, serological and virological parameters were investigated among 194 IDUs, 94 ex-IDUs and 95 non-IDUs that were sampled by the "snowball" technique in three localities renowned for both intense drug use and trafficking activities in Salvador, Brazil. The majority of the participants were male, but sex and mean age differed significantly between IDUs/ex-IDUs and non-IDUs ( $p<0.05)$. Anti-HCV screening revealed that $35.6 \%, 29.8 \%$ and $5.3 \%$ of samples from IDUs, ex-IDUs and non-IDUs, respectively, were seropositive. HCV-RNA detection confirmed that the prevalence of infection was $29.4 \%, 21.3 \%$ and $5.3 \%$ for IDUs, ex-IDUs and non-IDUs, respectively. Genotyping analysis among IDUs/ex-IDUs determined that $76.9 \%$ were infected with genotype 1, 18.5\% with genotype 3 and $4.6 \%$ with a mixed genotype; this result differed significantly from non-IDUs, where genotype 3 was the most frequent (60\%), followed by genotype $1(20 \%)$ and a mixed genotype (20\%). We report a significantly higher prevalence of HCV infection in IDUs/ex-IDUs compared to the control group $(p<0.001)$. Although the sample size of our study was small, the differences in HCV genotype distribution reported herein for IDUs/ex-IDUs and non-IDUs warrant further investigation.

Key words: HCV - injecting drug users - HCV genotypes - prevalence - Brazil

It is estimated that 130 million people worldwide are infected with HCV (Flaviviridae family, Hepacivirus genus and hepatitis $\mathrm{C}$ virus species), with an additional 3-4 million new infections occurring each year (The Global Burden of Hepatitis 2004, Alter 2007). Injecting drug users (IDUs) are considered to be the main risk group for $\mathrm{HCV}$ infection and act as a reservoir for this blood-borne virus. The seroprevalence of HCV varies between $31 \%$ to as high as $98 \%$ in different parts of the world (Memon \& Memon 2002). Unsurprisingly, the use of injecting drugs correlates strongly with $\mathrm{HCV}$ infection in Brazil (Carvalho et al. 1996, Oliveira et al. 1999a, Bastos et al. 2000). Risk factors such as polydrug use and the sharing of needles, syringes and equipment for drug injection are common among IDUs. In addition, there is little awareness of $\mathrm{HCV}$ and the associated risk of infection within this group (Vidal-Trecan et al. 2000). In the last decade, a declining prevalence of HCV infection has been described in IDUs in different countries, including Brazil (Lopes et al. 2009, Novais et al. 2009, Oliveira et al. 2009).

Financial support: CNPq (304713/2002-3, 40307112004-6), PRONEX (08283/07)

+Corresponding author: miter@bahia.fiocruz.br

Received 15 September 2009

Accepted 12 March 2010
$\mathrm{HCV}$ is classified into six different genotypes, each consisting of different subtypes. The different genotypes are known to differ in their distribution, depending on both geographic region and mode of transmission (Zein 2000). Of the different HCV genotypes, 1 and 3 are the predominant types among blood donors and other groups at risk for transfusion-transmitted infection, such as haemophiliacs and haemodialysis patients in Salvador, Brazil and IDUs in Europe (Bourliere et al. 2002, Silva et al. 2005, 2006). However, the HCV genotype distribution found in these groups may differ from the genotype distribution seen in the general population. (Guadagnino et al. 1997, Zarife et al. 2006). HCV is one of the few microorganisms for which genotyping, besides providing epidemiological information, also provides information with regard to treatment. Treatment is more frequently successful in cases of infection with genotype 2 or 3 than in cases of infection with other genotypes (Francois et al. 2009). From a public health perspective, it is important to know how HCV spreads in the community and how IDUs contribute to the transmission of this infection.

The data from several previous studies have highlighted the need to prevent the spread of HCV and other blood-borne infections among IDUs. In the present paper, we investigated the prevalence of $\mathrm{HCV}$ infection among IDUs, ex-IDUs and non-IDUs and the incidence of their respective $\mathrm{HCV}$ genotypes.

\section{PATIENTS, MATERIALS AND METHODS}

Study population and data collection - This investigation utilises data collected between 2000-2001 from a Brazilian multi-centre study called the AjUDE-Brasil 
II Project. This study was designed to assess HIV infection among IDUs, former drug users (ex-IDUs) and nonIDUs in the following six cities in Brazil: Salvador in the State of Bahia (BA), São José do Rio Preto in São Paulo (SP), Florianópolis and Itajaí in Santa Catarina and Porto Alegre and Gravataí in Rio Grande do Sul (Caiaffa 2001, Caiaffa et al. 2006, Cardoso et al. 2006). Informed consent, individual questionnaires and blood samples were collected from all participants. IDUs and ex-IDUs were defined as individuals who had injected drugs in the last two months and those who had injected drugs in the last five years but not in the last two months, respectively. Non-IDUs were drug users that sniffed or smoked cocaine and were defined as potential IDUs. Due to the availability of samples only individuals residing in the city of Salvador, the state capital of BA and the third largest city in Brazil, were included in the present study. The study area comprised three localities that were renowned for both intense drug use and trafficking activities and had implemented the Needle Exchange Program of the Federal University of Bahia (Andrade et al. 2001a, b, MS 2001). All study groups were sampled using the snowball technique (Frankel \& Frankel 1977, Biernacki \& Waldorf 1981). The participants were classified into the following three groups: 194 IDUs, 94 ex-IDUs and 95 non-IDUs.

Samples - Serum samples were collected from each individual for a primary HIV and HTLV study in 2000 (Andrade et al. 2001a, b). Briefly, within 2 h after venipuncture, all samples were aliquoted and stored immediately at $-70^{\circ} \mathrm{C}$ until use. For this study, we avoided RNA degradation by using only those aliquots that had not been thawed more than once prior to molecular testing.

Serology - Serological tests for anti-HCV detection were performed at the Bahia State Laboratory (LACEN/ SESAB) using commercially available automated immunoassays (MEIA, Axym System, Abbott) according to the manufacturer's instructions. HCV-RNA extraction was performed using the TRIzol LS reagent (Invitrogen, Carlsbad, CA, USA), according to the manufacturer's instructions. After precipitation and drying, HCV-RNA was immediately reverse transcribed into cDNA using random primers (Amersham Biosciences, Piscataway, NJ, USA).

HCV-RNA detection and genotyping - cDNA was detected by amplification of the 5' untranslated region (5' UTR) in nested PCR using primers 939, 209, 940 and 211, as described previously (Chan et al. 1992). The 251-bp (unlabelled) nested PCR product was analysed by electrophoresis using a $1.5 \%$ agarose gel in $1 \mathrm{X}$ Trisborate (TBE) buffer and visualised by ethidium bromide staining and ultraviolet (UV) light. Positive samples were genotyped by restriction fragment length polymorphism analysis according to a previously published method (Davidson et al. 1995). Briefly, restriction enzyme digests were carried out for $4-16 \mathrm{~h}$ at $37^{\circ} \mathrm{C}$ in the presence of 10 units each of (i) RsaI and HaeIII and (ii) Hinf I and MvaI. Digestion products were analysed by electrophoresis [4\% Metaphor agarose gel (BMA, ME, USA) in 1X TBE buffer containing $0.5 \mu \mathrm{g} / \mathrm{mL}$ ethidium bromide] and were visualised under UV light. Previously characterised genotypes were used as positive controls for genotypes 1,2 and 3. Genotypes were determined according to the Simmonds classification (Simmonds et al. 1993). Samples containing no or undetectable levels of HCV-RNA were re-extracted at least once more in an independent experiment. Negative individuals were tested again after six months to avoid potential false negative results.

Data analysis - The data were analysed using Epi Info, Version 6.04 (Centres for Disease Control and Prevention, USA). Fisher's exact test and the $\chi^{2}$ test (Yates corrected) were used to compare frequencies between groups when appropriate. In all tests, $\mathrm{p}$ values less than

TABLE

Serological and molecular results from the subjects enrolled in this study, in Salvador, Bahia, Brazil, 2000

\begin{tabular}{|c|c|c|c|}
\hline \multirow[b]{2}{*}{ Test } & \multicolumn{3}{|c|}{ Study groups } \\
\hline & $\begin{array}{l}\text { IDUs } \\
\%(n)\end{array}$ & $\begin{array}{l}\text { ex-IDUs } \\
\% \text { (n) }\end{array}$ & $\begin{array}{c}\text { non-IDUs } \\
\%(\mathrm{n})\end{array}$ \\
\hline Anti-HCV positivity & $35.6(69 / 194)$ & $29.8(28 / 94)$ & $5.3(5 / 95)$ \\
\hline HCV-RNA positivity ${ }^{a}$ & $83.8(57 / 68)$ & $76.9(20 / 26)$ & $100(5 / 5)$ \\
\hline $\begin{array}{l}\text { HCV confirmed infection } \\
(95 \% \mathrm{CI})\end{array}$ & $\begin{array}{c}29.4(57 / 194) \\
(23.2-34.5)\end{array}$ & $\begin{array}{c}21.3(20 / 94) \\
(13.8-27.7)\end{array}$ & $\begin{array}{c}5.3(5 / 95) \\
(1.1-9.5)\end{array}$ \\
\hline \multicolumn{4}{|l|}{ Genotype $^{a}$} \\
\hline $\begin{array}{l}1 \\
3 \\
\text { Mix }\end{array}$ & $\begin{array}{c}76.5(39 / 51) \\
19.6(10 / 51) \\
3.9(2 / 51)\end{array}$ & $\begin{array}{c}78.6(11 / 14) \\
14.3(2 / 14) \\
7.1(1 / 14)\end{array}$ & $\begin{array}{l}20.0(1 / 5) \\
60.0(3 / 5) \\
20.0(1 / 5)\end{array}$ \\
\hline
\end{tabular}

$a$ : total varies according to the availability of samples; CI: confidence interval: IDUs: injecting drug users. 
0.05 were considered statistically significant. Estimates for $95 \%$ confidence intervals $(95 \% \mathrm{CI})$ of prevalence were calculated using a resampling algorithm with a bootstrap value of 15,000 (BioEstat 4.0, PA, Brazil).

\section{RESULTS}

The majority of participants were male, composing $93.8 \%(182 / 194)$ of IDUs, $89.4 \%(84 / 94)$ of ex-IDUs and $80 \%$ (76/95) of non-IDUs. The mean age ( \pm standard deviation) was $26.6 \pm 7.7$ for IDUs, $27.8 \pm 6.9$ years for exIDUs and $23.7 \pm 6.4$ years for non-IDUs. Sex and mean age differed significantly between IDUs/ex-IDUs and non-IDUs $(\mathrm{p}<0.05)$.

HCV seroprevalence was significantly higher in IDUs and ex-IDUs, reaching 35.6\% (95\% CI 29.9-41.8\%) and $29.8 \%$ (95\% CI $21.3-37.2 \%)$, respectively, compared to $5.3 \%$ of non-IDUs $(95 \%$ CI $1.1-9.5 \%$; $p<0.05)$ (Table). Viraemia was detectable in the majority of the anti-HCV positive individuals in all three groups. The prevalence of HCV infection among IDUs/ex-IDUs was significantly higher compared to that of non-IDUs $(\mathrm{p}<0.05)$. It was calculated to be $29.4 \%$ (95\% CI 23.2-34.5\%) among IDUs, $21.3 \%$ (95\% CI 13.8-27.7\%) among ex-IDUs and $5.3 \%$ (95\% CI 1.1-9.5\%) among non-IDUs.

HCV genotype distribution was similar between IDUs and ex-IDUs but different among non-IDUs (Table). Among IDUs and ex-IDUs, genotype 1 was the most prevalent genotype, identified in $76.5 \%$ (39/51) of IDUs and $78.6 \%$ (11/14) of ex-IDUs, followed by genotype 3 , which was identified in $19.6 \%(10 / 51)$ of IDUs and $14.3 \%$ $(2 / 14)$ of ex-IDUs. Mixed genotypes were detected in $3.9 \%(2 / 51)$ of IDUs and 7.1\% (1/14) of ex-IDUs. Among non-IDUs, genotype 3 was the most prevalent genotype, identified in $60 \%(3 / 5)$ of the individuals, followed by genotype 1 and mixed genotype, both with $20 \%(1 / 5)$. None of the samples contained either genotype 2 or any other genotype. There was a significant difference in the HCV genotype distribution between IDUs/ex-IDUs and non-IDUs $(\mathrm{p}<0.05)$. Some samples could not be genotyped due to low quantity of available serum.

\section{DISCUSSION}

The snowball sampling used in this project is a common technique used in the assessment of hidden populations where existing study subjects recruit future subjects from among their acquaintances. The present paper is not intended to be inferential because the samples were collected in a non-random way. However, the comparison of the HCV positivity and HCV genotype distribution between the groups of IDUs/ex-IDUs and non-IDUs seems to be consistent with a history of drug use and a common source of infection, respectively.

It has been shown that HCV prevalence among different populations is higher between the ages of 24-35 (Oliveira et al. 1999b, Bastos et al. 2000, Kapadia et al. 2002). The mean age of IDUs and ex-IDUs enrolled in the present study was $26.6 \pm 7.7$ and $27.8 \pm 6.9$ years, respectively. However, needle sharing among individuals belonging to either of these groups led to a five-fold increase in the transmission of HCV compared to nonIDUs. A previous study performed in Salvador and Rio de Janeiro showed that the first shot typically occurs at around 15 years of age (Andrade et al. 2001a, b, Oliveira et al. 2006). Therefore, IDUs are important reservoirs for $\mathrm{HCV}$ because they are infected at a much earlier age and have a higher risk of HIV co-infection or other parenterally transmitted viruses, which make HCV more difficult to eliminate.

This study confirms that HCV seroprevalence is significantly higher among IDUs and ex-IDUs $(35.6 \%$ and $29.8 \%$, respectively) compared to non-IDUs $(5.3 \%)$. However, this was lower than that reported for studies of IDUs in the cities of Santos (SP) and Rio de Janeiro and for a previous study in Salvador (BA) $(74 \%, 69.8 \%$ and $77 \%$, respectively) (Carvalho et al. 1996, Carvalho et al. 1999, MS 2001). The lower seroprevalence observed in our study may be due to the introduction of a harm reduction program in Salvador by the Federal University of Bahia that began four years earlier in the same areas where individuals were recruited. This program resulted in a reduction of needle sharing from $40-17 \%$ (Andrade et al. 2001a, b). In countries such as England and Australia, the AIDS prevention programs and harm reduction programs resulted in a concurrent decrease of $\mathrm{HCV}$ infection among IDUs (MacDonald et al. 2000, Hope et al. 2001). Of note, HCV seroprevalence in non-IDUs was higher than that observed for the general population of Salvador (5.3\% vs. $1.5 \%$ ) (Zarife et al. 2006). Because the majority of the non-IDUs recruited for this study were cocaine drug users, this difference may be attributable to the sharing of contaminated implements such as straws that are commonly used to inhale this drug (McMahon et al. 2004).

HCV-RNA was detected in more than $70 \%$ of the seropositive individuals; this represents a final HCV prevalence of infection of $29.4 \%$ among IDUs, which is less than that of haemophiliacs (32.6\%) (Silva et al. 2006) and chronic hepatitis outpatients from the same locality ( $>50 \%$, unpublished observations). IDUs are currently the main source of infection for persons with hepatitis C (Alter \& Seeff 2000, Farci \& Purcell 2000). It is well known that such individuals tend to develop a chronic infection, ultimately leading to chronic hepatitis. Many of these individuals are not clinically ill and are therefore not aware of their infection, leading to activities that contribute to an increase in the incidence of HCV (Vidal-Trecan et al. 2000). Such activities include needle/syringe/equipment sharing, tattooing and body/ ear piercing.

HCV genotype distribution varies geographically. Genotypes 1,2 and 3 are mostly cosmopolitan, while genotypes 4 and 5 are predominant in Africa and genotype 6 is found in Asia (Simmonds et al. 1993). Several studies in Brazil have reported that HCV genotype 1 is more prevalent than genotype 3 among patients who had received a blood transfusion (Silva et al. 2005, 2006). Two population-based studies, one conducted in Italy and another in Brazil, identified a possible switch in the prevalence of these genotypes in the general population, indicating that specific risk factors may play a role in HCV transmission (Guadagnino et al. 1997, Zarife et al. 2006). Our study is the first report on the HCV geno- 
type distribution among IDUs in Salvador. The most prevalent genotype among IDUs and ex-IDUs was genotype 1 , followed by genotype 3 and mixed infection of genotypes 1 and 3 . Of note, genotype 3 was the most predominant among non-IDUs, similar to a previous report for the general population of Salvador (Zarife et al. 2006). Considering that injection of cocaine is the only difference among IDUs/ex-IDUs and non-IDUs, these data emphasise the importance of needle sharing to the acquisition of genotype 1 . However, the number of samples that tested positive for HCV among the non-IDUs was small; therefore, further studies will be required to confirm the frequency of genotype 3 in this group.

Finally, we demonstrated a decrease in the seroprevalence of $\mathrm{HCV}$ among IDUs from 77-35.6\%; however, this result does not eliminate the need for public health interventions focusing on the transmission of $\mathrm{HCV}$ in this group (Carvalho et al. 1999, MS 2001). As IDUs are at high risk for parenteral infection, this group could be a better sentinel population for parenteral infection than blood donor candidates for molecular epidemiology purposes. The difference in the HCV genotype distribution observed among IDUs and ex-IDUs when compared to the general population could be attributed to the study design because the non-random sampling intrinsic to the use of the snowball technique may result in an over or under-representation of a given genotype with regard to its actual distribution in the population of IDUs living in the communities under analysis.

\section{ACKNOWLEDGEMENTS}

To Dr. Bernardo Galvão and Noilson Lázaro Sousa Gonçalves, from the Public Health Advanced Laboratory-Fiocruz, for storing the sera samples until they were used in this study, and Dr. Alan Mcbride, for careful reading and review of the manuscript.

\section{REFERENCES}

Alter HJ, Seeff LB 2000. Recovery, persistence and sequelae in hepatitis $\mathrm{C}$ virus infection: a perspective on long-term outcome. Semin Liver Dis 20: 17-35.

Alter MJ 2007. Epidemiology of hepatitis C virus infection. World $J$ Gastroenterol 13: 2436-2441.

Andrade T, Lurie P, Medina MG, Anderson K, Dourado I 2001a. The Opening of South America's First Needle Exchange Program and an epidemic of crack use in Salvador, Bahia-Brazil. AIDS Behav 5: 51-64.

Andrade TM, Dourado I, Farias AH, Castro BG 2001b. Redução de danos e redução de prevalência de infecção pelo HIV entre usuários de drogas injetáveis em Salvador, Bahia. In TM Andrade, I Dourado, AH Farias, BG Castro (eds.), Coordenação Nacional de DST/AIDS-MS (org.), A contribuição dos estudos multicêntricos frente a epidemia de HIVIAIDS entre UDI no Brasil: 10 anos de pesquisa e redução de danos, Secretaria de Políticas da Saúde - Coordenação Nacional de DST/AIDS - Ministério da Saúde, Brasília, p. 95-113.

Bastos FI, Lowndes CM, Castello-Branco LR, Linhares-de-Carvalho MI, Oelemann W, Bernier F, Morgado MG, Yoshida CF, Rozental T, Alary M 2000. Sexual behaviour and infection rates for HIV, blood-borne and sexually transmitted infections among patients attending drug treatment centres in Rio de Janeiro, Brazil. Int $J$ STD AIDS 11: 383-392.
Biernacki P, Waldorf D 1981. Snowball sampling: problems and techniques of chains referral sampling. Sociol Methods Res 10: $141-163$.

Bourliere M, Barberin JM, Rotily M, Guagliardo V, Portal I, Lecomte L, Benali S, Boustiere C, Perrier H, Jullien M, Lambot G, Loyer R, LeBars O, Daniel R, Khiri H, Halfon P 2002. Epidemiological changes in hepatitis $\mathrm{C}$ virus genotypes in France: evidence in intravenous drug users. J Viral Hepat 9: 62-70.

Caiaffa WT 2001. Projeto AjUDe-Brasil: avaliaçäo epidemiológica dos usuários de drogas injetáveis dos projetos de reduçäo de danos apoiados pela CN-DST/AIDS, (Avaliaçäo 6), Ministério da Saúde, Brasília, 341 pp.

Caiaffa WT, Bastos FI, Freitas LL, Mingoti SA, Proietti FA, Carneiro-Proietti AB, Gandolfi D, Doneda D 2006. The contribution of two Brazilian multi-center studies to the assessment of HIV and HCV infection and prevention strategies among injecting drug users: the AjUDE-Brasil I and II Projects. Cad Saude Publica 22: 771-782.

Cardoso MN, Caiaffa WT, Mingoti SA 2006. AIDS incidence and mortality in injecting drug users: the AjUDE-Brasil II Project. Cad Saude Publica 22: 827-837.

Carvalho H, Santos V, Sabino E, Andrade T, Bueno R, Massad E 1999. HIV, hepatitis B and C and syphilis seroprevalence and risky behaviour among IDUs of two Brazilian cities - Santos and Salvador, Abstract of the 10th International Conference on the Reduction of Drug Related Harm, São Paulo, p. 60.

Carvalho HB, Mesquita F, Massad E, Bueno RC, Lopes GT, Ruiz MA, Burattini MN 1996. HIV and infections of similar transmission patterns in a drug injectors community of Santos, Brazil. J Acquir Immune Defic Syndr Hum Retrovirol 12: 84-92.

Chan SW, McOmish F, Holmes EC, Dow B, Peutherer JF, Follett E, Yap PL, Simmonds P 1992. Analysis of a new hepatitis C virus type and its phylogenetic relationship to existing variants. J Gen Virol 73: 1131-1141.

Davidson F, Simmonds P, Ferguson JC, Jarvis LM, Dow BC, Follett EA, Seed CR, Krusius T, Lin C, Medgyesi GA 1995. Survey of major genotypes and subtypes of hepatitis $C$ virus using RFLP of sequences amplified from the 5' non-coding region. J Gen Virol 76: $1197-1204$.

Farci P, Purcell RH 2000. Clinical significance of hepatitis C virus genotypes and quasispecies. Semin Liver Dis 20: 103-126.

Francois C, Castelain S, Duverlie G, Capron D, Nguyen-Khac E 2009. Optimizing the treatment of chronic viral hepatitis C. Expert Rev Gastroenterol Hepatol 3: 607-613.

Frankel MR, Frankel LR 1977. Some recent developments in sample survey design. J Mark Res 14: 280-293.

Guadagnino V, Stroffolini T, Rapicetta M, Costantino A, Kondili LA, Menniti-Ippolito F, Caroleo B, Costa C, Griffo G, Loiacono L, Pisani V, Foca A, Piazza M 1997. Prevalence, risk factors and genotype distribution of hepatitis $\mathrm{C}$ virus infection in the general population: a community-based survey in southern Italy. Hepatology 26: 1006-1011.

Hope VD, Judd A, Hickman M, Lamagni T, Hunter G, Stimson GV, Jones S, Donovan L, Parry JV, Gill ON 2001. Prevalence of hepatitis $\mathrm{C}$ among injection drug users in England and Wales: is harm reduction working? Am J Public Health 91: 38-42.

Kapadia F, Vlahov D, Des Jarlais DC, Strathdee SA, Ouellet L, Kerndt P, Morse EE, Williams I, Garfein RS 2002. Does bleach disinfection of syringes protect against hepatitis $\mathrm{C}$ infection among young adult injection drug users? Epidemiology 13: 738-741.

Lopes CL, Teles SA, Espirito-Santo MP, Lampe E, Rodrigues FP, Motta-Castro AR, Marinho TA, Reis NR, Silva AM, Martins 
RM 2009. Prevalence, risk factors and genotypes of hepatitis C virus infection among drug users, Central-Western Brazil. Rev Saude Publica 43 (Suppl. 1): 43-50.

MacDonald MA, Wodak AD, Dolan KA, van Beek I, Cunningham PH, Kaldor JM 2000. Hepatitis C virus antibody prevalence among injecting drug users at selected needle and syringe programs in Australia, 1995-1997. Collaboration of Australian NSPs. Med J Aust 172: 57-61.

McMahon JM, Simm M, Milano D, Clatts M 2004. Detection of hepatitis $\mathrm{C}$ virus in the nasal secretions of an intranasal drug-user. Ann Clin Microbiol Antimicrob 3: 6.

Memon MI, Memon MA 2002. Hepatitis C: an epidemiological review. J Viral Hepat 9: 84-100.

MS - Ministério da Saúde - Brasil 2001. Contribuição dos estudos multicêntricos frente à epidemia de HIV/AIDS entre UDI no Brasil. Dez anos de pesquisa em redução de danos. [updated 2001; cited 200914 December]. Available from: http://www.aids.gov. br/avalia8/index.htm.

Novais AC, Lopes CL, Reis NR, Silva AM, Martins RM, Souto FJ 2009. Prevalence of hepatitis $C$ virus infection and associated factors among male illicit drug users in Cuiabá, Mato Grosso, Brazil. Mem Inst Oswaldo Cruz 104: 892-896.

Oliveira ML, Bastos FI, Sabino RR, Paetzold U, Schreier E, Pauli G, Yoshida CF 1999a. Distribution of HCV genotypes among different exposure categories in Brazil. Braz J Med Biol Res 32: $279-282$.

Oliveira ML, Bastos FI, Telles PR, Yoshida CF, Schatzmayr HG, Paetzold U, Pauli G, Schreier E 1999b. Prevalence and risk factors for $\mathrm{HBV}, \mathrm{HCV}$ and $\mathrm{HDV}$ infections among injecting drug users from Rio de Janeiro, Brazil. Braz J Med Biol Res 32: 1107-1114.

Oliveira ML, Hacker MA, Oliveira SA, Telles PR, Ó KM, Yoshida CF, Bastos FI 2006. "The first shot": the context of first injection of illicit drugs, ongoing injecting practices and hepatitis $\mathrm{C}$ infection in Rio de Janeiro, Brazil. Cad Saude Publica 22: 861-870.

Oliveira ML, Yoshida CF, Telles PR, Hacker MA, Oliveira SA, Miguel JC, do O KM, Bastos FI 2009. Trends in HCV prevalence, risk factors and distribution of viral genotypes in injecting drug users: findings from two cross-sectional studies. Epidemiol Infect 137: 970-979.

Silva LK, Silva MB, Lopes GB, Rodart IF, Costa FQ, Santana NP, Parana R, Santana A, Reis MG 2005. Prevalence of hepatitis C virus infection and $\mathrm{HCV}$ genotypes among hemophiliacs in the state of Bahia, Northeastern Brazil: analysis of serological and virological parameters. Rev Soc Bras Med Trop 38: 496-502.

Silva LK, Silva MB, Rodart IF, Lopes GB, Costa FQ, Melo ME, Gusmao E, Reis MG 2006. Prevalence of hepatitis C virus (HCV) infection and HCV genotypes of hemodialysis patients in Salvador, Northeastern Brazil. Braz J Med Biol Res 39: 595-602.

Simmonds P, Holmes EC, Cha TA, Chan SW, McOmish F, Irvine B, Beall E, Yap PL, Kolberg J, Urdea MS 1993. Classification of hepatitis $\mathrm{C}$ virus into six major genotypes and a series of subtypes by phylogenetic analysis of the NS-5 region. J Gen Virol 74: 2391-2399.

The Global Burden of Hepatitis CWG 2004. Global Burden of Disease (GBD) for Hepatitis C. J Clin Pharmacol 44: 20-29.

Vidal-Trecan G, Coste J, Varescon-Pousson I, Christoforov B, Boissonnas A 2000. HCV status knowledge and risk behaviours amongst intravenous drug users. Eur J Epidemiol 16: 439-445.

Zarife MA, Silva LK, Silva MB, Lopes GB, Barreto ML, Teixeira Mda G, Dourado I, Reis MG 2006. Prevalence of hepatitis C virus infection in North-eastern Brazil: a population-based study. Trans R Soc Trop Med Hyg 100: 663-668.

Zein NN 2000. Clinical significance of hepatitis C virus genotypes. Clin Microbiol Rev 13: 223-235. 